\title{
Primary Intracranial Leiomyoma in Immunocompetent Patients: Case Report, Review of Literature and Treatment Recommendations
}

Linden E Fornoff', Kyle S Nelson'1, Rodney D McComb², Leslie C Hellbusch ${ }^{1}$ and Michele R Aizenberg ${ }^{1 *}$

${ }^{1}$ Division of Neurosurgery, University of Nebraska Medical Center, Omaha, NE, USA

${ }^{2}$ Department of Pathology and Microbiology, University of Nebraska Medical Center, Omaha, NE, USA

\section{Abstract}

Objective: Primary intracranial leiomyomas are rare tumors. These tumors are mostly described in immunocompromised patients and associated with Epstein-Barr virus (EBV). The following report is an intracranial leiomyoma that was resected twice from a young, immunocompetent male.

Methods: This is a report of a patient who initially presented with tremor and headaches. He was ultimately found to have a large $6 \mathrm{~cm} \times 8 \mathrm{~cm}$ tumor that was removed. Nine years later, he was found to have a small recurrence that was removed. No adjuvant therapies have been given.

Results: His follow-up totals well over 11 years and he remains on observation. Extensive review of this rare entity is provided.

Conclusion: It is suggested that observation without any adjuvant therapy be the treatment of choice after resection of primary intracranial leiomyomas. These uncommon, benign tumors should be followed long-term given their slow-growing nature.

Keywords: Immunocompetent; Intracranial leiomyoma; Intracranial tumors; Smooth muscle cell tumor

\section{Introduction}

Leiomyomas, benign neoplasms of mesenchymal origin, are quite common in places such as the gastrointestinal and genitourinary tracts. They are comprised of well-differentiated smooth muscle cells with few mitotic figures [1]. By convention, leiomyomas should not exhibit metastatic potential, though there have been several reported cases of metastatic leiomyomas to the lungs, heart, lymph nodes, intraperitoneal cavity, soft tissue and muscle, breast, peripheral nerves, spinal cord and skull base [2-4]. Primary intracranial lesions remain rare. Only 17 such cases have been reported and of those, only 3 are in confirmed immunocompetent patients (Table 1) [1,5-18]. The following case is that of a 20 year-old immunocompetent male who underwent two resections of his primary, middle intracranial fossa leiomyoma with 135-month follow-up.

\section{Case Report}

\section{History}

A 20 year-old right handed Caucasian male presented in October 2001 with right-sided arm and lip tremor, weight loss, and headaches. Imaging showed a $6 \mathrm{~cm} \times 8 \mathrm{~cm}$ tumor originating in the left middle fossa (Figures 1A and B). Surgical removal was recommended at this time and a combined neurosurgery/neuro-otology approach was performed. The tumor was quite vascular. It was noted at the time of surgery that the tumor invaded the temporal bone into the soft tissues and also involved the dura. Following gross total resection, the tumor was found to be a well-differentiated, Epstein-Barr virus (EBV) negative, primary intracranial smooth muscle tumor. A subsequent complete workup revealed no other sites of disease. No adjuvant therapy was recommended secondary to achieving gross total resection (Figures $1 \mathrm{C}$ and $1 \mathrm{D})$. Postoperatively, the patient developed a slight expressive aphasia and a partial right homonymous hemianopia; both had complete resolution. Nine months postoperatively, the patient presented with seizures and was started on lamotrigine with adequate control. Over the following four years, the patient had routine follow-up imaging that did not show any recurrence of the tumor. The patient was then lost to neurosurgical follow-up and had remained asymptomatic and seizurefree off lamotrigine until 2010. At this time, a CT scan was obtained to evaluate hearing loss. A small encephalocele from the prior operation was thought to be contributing to a conductive hearing loss. An MRI was performed that showed an $8 \mathrm{~mm}$ tumor recurrence in the floor of

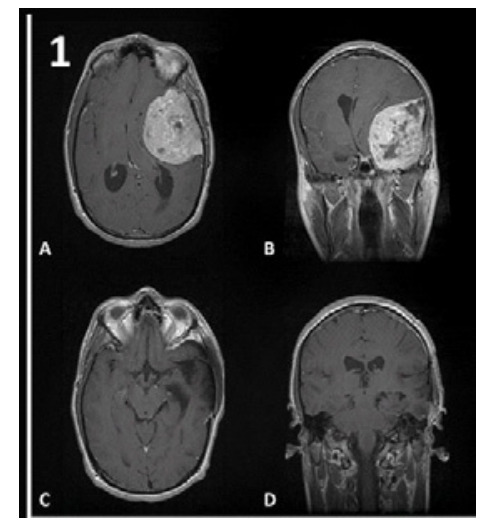

Figure 1: (A and B) Axial and coronal, pre-operative, post-contrast T1 MR of middle fossa tumor. (C and D) Axial and coronal post-contrast T1 MRI showing gross total resection.

*Corresponding author: Michele R. Aizenberg, M.D., Section of Neurosurgery, University of Nebraska Medical Center, 982035 Nebraska Medical Center, Omaha, NE 68198-2035, USA, Tel: 402-559-9614; Fax: 402-559-7779; E-mail: maizenberg@unmc.edu

Received January 15 2013; Accepted February 16, 2013; Published February 18, 2013

Citation: Fornoff LE, Nelson KS, McComb RD, Hellbusch LC, Aizenberg MR (2013) Primary Intracranial Leiomyoma in Immunocompetent Patients: Case Report, Review of Literature and Treatment Recommendations. J Neurol Disord 1 : 102. doi:10.4172/2329-6895.1000102

Copyright: ( 2013 Fornoff LE, et al. This is an open-access article distributed under the terms of the Creative Commons Attribution License, which permits unrestricted use, distribution, and reproduction in any medium, provided the original author and source are credited. 
Citation: Fornoff LE, Nelson KS, McComb RD, Hellbusch LC, Aizenberg MR (2013) Primary Intracranial Leiomyoma in Immunocompetent Patients:

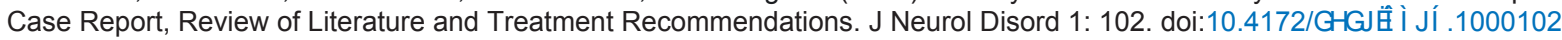

Page 2 of 4

\begin{tabular}{|c|c|c|c|c|c|c|c|c|c|c|}
\hline Patient & $\begin{array}{l}\text { Author } \\
\text { Year }\end{array}$ & $\begin{array}{l}\text { Age } \\
\text { (years) } \\
\text { Sex }\end{array}$ & $\begin{array}{l}\text { Size } \\
(\mathrm{cm})\end{array}$ & Location & $\begin{array}{l}\text { Immune } \\
\text { Status }\end{array}$ & \begin{tabular}{|l} 
EBV \\
Status
\end{tabular} & Pathological features & Surgery & $\begin{array}{l}\text { Adjuvant } \\
\text { therapy }\end{array}$ & $\begin{array}{l}\text { Follow-up } \\
\text { (months) } \\
\text { Status }\end{array}$ \\
\hline \multicolumn{11}{|c|}{ Immunocompetent } \\
\hline \multirow[t]{4}{*}{ Adult } & Hua et al. [1] & $35 \mathrm{M}$ & 3.0 & $\begin{array}{l}\text { R middle fossa; } \\
\text { extradural }\end{array}$ & (-): HIV & -- & $\begin{array}{l}\text { (+): SMA, vimentin } \\
\text { (-): S100, EMA, CD34, MIB-1 }\end{array}$ & GTR & None & $\begin{array}{l}18 \\
N R\end{array}$ \\
\hline & Hua et al. [1] & $45 \mathrm{M}$ & 2.0 & $\begin{array}{l}\text { L middle fossa; } \\
\text { intradural }\end{array}$ & (-): HIV & -- & $\begin{array}{l}\text { (+): SMA, vimentin, MSA } \\
(-): \text { S100, EMA, MIB-1, CK }\end{array}$ & GTR & None & $\begin{array}{l}14 \\
\text { NR }\end{array}$ \\
\hline & Fornoff et al. & $20 \mathrm{M}$ & 8.0 & $\begin{array}{l}\text { L middle fossa; } \\
\text { Intradural, extradural }\end{array}$ & (-): HIV & $(-)$ & $(+)$ : SMA, myosin, Ki-67<1\% & GTR & None & $\begin{array}{l}135 \\
\operatorname{Rec}\end{array}$ \\
\hline & Dorwal et al. [8] & $17 \mathrm{M}$ & 6.0 & $\begin{array}{l}\text { L infratemporal fossa; } \\
\text { cavernous,ethmoid, } \\
\text { sphenoid sinuses; } \\
\text { intradural }\end{array}$ & $(-):$ HIV & $(-)$ & $\begin{array}{l}\text { (+): SMA, vimentin, caldesmon } \\
(-) \text { : S100, CD34, EMA }\end{array}$ & STR & None & -- \\
\hline \multicolumn{11}{|c|}{ Immunocompromised } \\
\hline \multirow[t]{5}{*}{ Adult } & $\begin{array}{l}\text { Kleinschmidt- } \\
\text { DeMasters et al. } \\
\text { [11], Case } 4\end{array}$ & $34 \mathrm{~F}$ & 1.2 & $\begin{array}{l}\text { R cavernous sinus; } \\
\text { intradural }\end{array}$ & (+): HIV & $(+)$ & (+): MSA, desmin, EBV RNA & STR & None & 4.5 \\
\hline & Karpinski et al. [9] & $26 \mathrm{M}$ & 3.0 & $\begin{array}{l}\text { 1. L sphenoid ridge; } \\
\text { intradural } \\
\text { 2. C2/C3 lesion: intra- } \\
\text { dural, extramedullary }\end{array}$ & (+): HIV & $(+)$ & $\begin{array}{l}\text { (+): actin, EBV } \\
\text { (-): EMA, S100 }\end{array}$ & STR & None & -- \\
\hline & Bargiela et al. [6] & $32 \mathrm{~F}$ & 5.0 & $\begin{array}{l}\text { L occipital lobe; } \\
\text { intradural }\end{array}$ & (+): HIV & -- & $\begin{array}{l}(+): \text { MSA, desmin, low mitotic } \\
\text { activity }\end{array}$ & Autopsy & -- & -- \\
\hline & $\begin{array}{l}\text { Citow and Kranzler } \\
{[7]}\end{array}$ & $31 \mathrm{~F}$ & 3.0 & $\begin{array}{l}\text { 1. } R \text { clivus, intradural } \\
\text { 2. } R \text { upper lobe of lung }\end{array}$ & (+): HIV & ND & $\begin{array}{l}(+): \text { low MIB-1 } \\
(-): \text { p53, EBV ND }\end{array}$ & STR & None & -- \\
\hline & Zevgaridis et al. [17] & $45 \mathrm{~F}$ & 4.0 & $\begin{array}{l}\text { L temporal pole; } \\
\text { intradural }\end{array}$ & $\begin{array}{l}\text { Post-trans- } \\
\text { plant }\end{array}$ & $(+)^{\mathrm{a}}$ & $(+)$ : SMA, desmin, EBV & GTR & None & $\begin{array}{l}84 \\
\text { NR }\end{array}$ \\
\hline \multirow[t]{2}{*}{ Pediatric } & $\begin{array}{l}\text { Kumar et al. } \\
{[13]}\end{array}$ & $10 \mathrm{M}$ & 4.0 & $\begin{array}{l}\mathrm{R} \text { basal ganglia; } \\
\text { intradural }\end{array}$ & (+): HIV & $(+)$ & $\begin{array}{l}(+): \text { SMA, MSA, desmin, EBV, } \\
\text { rare mitoses } \\
(-): \text { S100 }\end{array}$ & GTR & None & $\begin{array}{l}6 \\
\text { NR }\end{array}$ \\
\hline & $\begin{array}{l}\text { Aizenberg } \\
\text { Unpublished }\end{array}$ & $8 \mathrm{~F}$ & $\begin{array}{l}0.8 \\
2.5\end{array}$ & $\begin{array}{l}\text { 1. frontal; intradural } \\
\text { 2. sylvian fissure; } \\
\text { intradural }\end{array}$ & $\begin{array}{l}\text { Post-trans- } \\
\text { plant }\end{array}$ & $(+)^{\mathrm{a}}$ & $\begin{array}{l}\text { (+): SMA, EBV, Ki-67 8-20\% } \\
\text { (-): CD34, EMA, GFAP }\end{array}$ & GTR & $\begin{array}{l}\text { Neoadjuvant } \\
\text { Ganciclovir }\end{array}$ & $\begin{array}{l}35 \\
\text { NR }\end{array}$ \\
\hline \multicolumn{11}{|c|}{ Immune status unknown } \\
\hline \multirow[t]{6}{*}{ Adult } & Bette et al. [11] & $56 \mathrm{~F}$ & 3.2 & $\begin{array}{l}\text { sellar/suprasellar; } \\
\text { intradural }\end{array}$ & -- & $(-)$ & $\begin{array}{l}\text { (+): MSA, vimentin, S100 in } \\
\text { cytoplasm } \\
\text { (-): myoglobin, desmin, ER, PR, } \\
\text { GFAP, EMA, pancytokeratin, } \\
\text { EBV }\end{array}$ & GTR & None & $\begin{array}{l}6 \\
\text { NR }\end{array}$ \\
\hline & Ali et al. [5] & $29 \mathrm{~F}$ & 1.2 & $\begin{array}{l}R \text { frontal floor; } \\
\text { intradural }\end{array}$ & -- & $(-)$ & $\begin{array}{l}\text { (+): SMA, MSA, Collagen IV } \\
\text { desmin, caldesmon, } \\
\text { Ki-67<1\% } \\
\text { (-): keratin, EMA, S100, CD117, } \\
\text { ER, PR, CD34, CD30, EBV }\end{array}$ & GTR & None & -- \\
\hline & Kim et al. [10] & $40 \mathrm{~F}$ & 7.0 & $\begin{array}{l}\text { R tempal parietal; } \\
\text { intradural }\end{array}$ & -- & -- & (+): vimentin, SMA & GTR & None & -- \\
\hline & Kroe et al. [12] & $68 \mathrm{~F}$ & 3.0 & sellar; intradural & -- & -- & $\begin{array}{l}\text { Diagnosis was based solely on } \\
\text { histologic appearance }\end{array}$ & STR & None & $\begin{array}{l}9 \\
\text { NR }\end{array}$ \\
\hline & $\begin{array}{l}\text { Kazumoto and } \\
\text { Matzumoto [18] }\end{array}$ & $38 \mathrm{~F}$ & 3.5 & $\begin{array}{l}\text { R temporal lobe; } \\
\text { intradural }\end{array}$ & -- & -- & $\begin{array}{l}\text { (+): SMA, vimentin, desmin } \\
(-) \text { : GFAP, human factor } 8 \\
\text { related antigen }\end{array}$ & GTR & None & $\begin{array}{l}10 \\
N R\end{array}$ \\
\hline & Lin et al. [14] & $20 \mathrm{~F}$ & 3.0 & $\begin{array}{l}\text { L temporal and insular; } \\
\text { intradural }\end{array}$ & -- & -- & $\begin{array}{l}\text { (+): vimentin, muscle actin, } \\
\text { desmin } \\
(-): \text { S100, neurofilament, GFAP, } \\
\text { EMA, ER, cytokeratin }\end{array}$ & $\mathrm{Bx}$ & None & $\begin{array}{l}10 \\
N R\end{array}$ \\
\hline \multirow[t]{2}{*}{ Pediatric } & $\begin{array}{l}\text { Thierauf and Wei- } \\
\text { land [15] }\end{array}$ & $4 \mathrm{~F}$ & 5.0 & $\begin{array}{l}\text { suprasellar; } \\
\text { intradural }\end{array}$ & -- & -- & $\begin{array}{l}\text { Diagnosis was based solely on } \\
\text { histologic appearance }\end{array}$ & STR & None & -- \\
\hline & Wang et al. [16] & $12 \mathrm{M}$ & -- & $\begin{array}{l}\text { R temporal; } \\
\text { intradural }\end{array}$ & -- & -- & $\begin{array}{l}\text { (+): SMA } \\
\text { (-): S100, GFAP, vimentin, } \\
\text { desmin, neuron specific enolase }\end{array}$ & GTR & None & $\begin{array}{l}56 \\
\text { NR }\end{array}$ \\
\hline
\end{tabular}

Table 1:

a=status post solid organ transplant and subsequent immunosuppressive therapy.

Bx=Biopsy; CK=Cytokeratin; EMA=Epithelial Membrane Antigen; ER=Estrogen Receptor; GFAP=Glial Fibrillary Acidic Protein; GTR=Gross Total Resection; L=Left; MIB$1=$ Monoclonal Antibody against Ki-67 antigen; MSA=Muscle-Specific Actin; ND=Non-Diagnostic; NR=No Recurrence; PR=Progesterone Receptor; Prog=Progression; $\mathrm{R}=$ Right; Rec=Recurrence; SMA=Smooth Muscle Actin; STR=Subtotal Resection

middle fossa (Figures $2 \mathrm{~A}$ and $2 \mathrm{~B}$ ). In addition, there was a separate 1.5 $\mathrm{cm}$ lesion in the left frontal bone which was also appreciated on clinical examination (Figures 2C and 2D). The patient sought a neurosurgical opinion in regards to the recurrent tumor.

\section{Operation}

A joint operation with neuro-otology and neurosurgery was performed in order to address both issues of hearing loss and tumor 
Citation: Fornoff LE, Nelson KS, McComb RD, Hellbusch LC, Aizenberg MR (2013) Primary Intracranial Leiomyoma in Immunocompetent Patients:

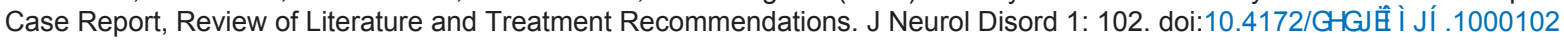

Page 3 of 4

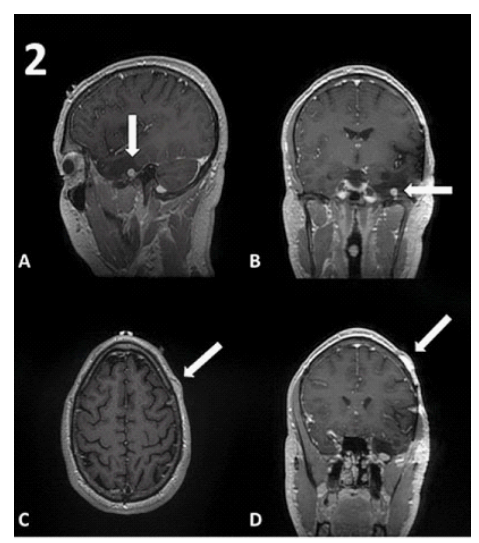

Figure 2: (A and B) Sagittal and coronal post-contrast T1 MRI showing middle fossa recurrence (arrows). (C and D) Axial and coronal post-contrast T1 MRI showing left frontal skull tumor (recurrence).

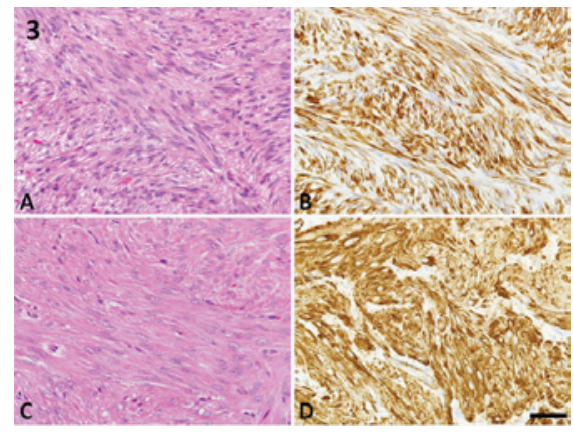

Figure 3: A: The tumor from the first operation consists of fascicles of spindle cells with elongated nuclei. B: Desmin is diffusely expressed. C: The recurrent tumor consists of well-differentiated smooth muscle with abundant eosinophilic cytoplasm. D: There is diffuse expression of smooth-muscle myosin.

$H$ \& $E(A, C)$. Immunohistochemistry for desmin (B) and smooth-muscle myosin (D).

All at the same magnification bar $=50$ microns.

recurrence. A redo left front temporal craniotomy, resection of the middle fossa tumor recurrence, left frontal craniectomy, removal of frontal bone tumor, lumbar drain placement, and redo cranioplasty with titanium mesh were performed by neurosurgery. The frontal tumor was found to be intraosseous. This tumor was thought to be a recurrence from the original tumor as well as the middle fossa tumor. The patient tolerated the procedure well without complications. The post-operative MRI showed gross total resection of both areas of tumor recurrence.

\section{Pathological findings}

First operation: The original tumor was a smooth muscle neoplasm composed of intersecting fascicles of spindle cells with eosinophilic cytoplasm and elongated blunt-ended nuclei with small nucleoli (Figure 3A). There was focal degenerative-type necrosis with fibrosis and dystrophic calcification. Mitoses were rare and difficult to find. The Ki67 immunolabeling index was 1.3\%. Tumor cells showed strong diffuse expression of smooth muscle actin, muscle-specific actin, and desmin by immunohistochemistry (Figure 3B). In situ hybridization (ISH) for Epstein-Barr virus early RNA (EBER) was negative. Immunostains for S100 protein, EMA, GFAP, and latent membrane protein (EBV) were negative. Due to the presence of bone invasion, the malignant potential was considered uncertain.
Second operation: The recurrent tumors from the left frontal bone and left middle temporal fossa were morphologically similar. Both appeared more differentiated than the original tumor, as evidenced by abundant eosinophilic cytoplasm and the formation of distinct bundles of smooth muscle (Figure 3C). Only a rare mitosis was encountered, and there was no necrosis. The Ki67 immunolabeling index was $2 \%$. The tumor cells showed strong diffuse expression of smooth muscle actin and smooth muscle myosin (Figure 3D). ISH for EBER was negative. Invasion of bone in the left frontal region was confirmed.

\section{Postoperative course}

Postoperatively, the patient did well and remained neurologically intact. The postoperative imaging revealed gross total resection. Again, no adjuvant therapy was recommended given the slow growing nature of this tumor, the extent of resection, and the pathological findings. Five months post-resection, the patient presented with a seizure and was restarted on lamotrigine without further seizure activity. The patient continues to be recurrence-free 24 months after the second resection, for a total survival length of 135 months from the initial diagnosis in 2001. Surveillance imaging was every six months, consisting of MRI with and without contrast to assess for tumor recurrence. This was recently extended to one year intervals.

\section{Discussion}

Primary intracranial leiomyomas are a rare entity and even rarer in an immunocompetent patient. The majority of intracranial leiomyomas are discovered in immunocompromised patients [3,5-7,9,11,17]. Their immunosuppression stems from HIV infection, pharmacologic suppression after organ transplantation, or genetic disorders such as common variable immunodeficiency syndrome. Many of the lesions in this patient population are positive for EBV [3,5-7,9,11,17]. In our patient, however, the immune system was intact and the lesion was negative for EBV, making a total of 4 cases in the immunocompetent patient reported in the literature $[1,5,8,11]$.

Though there seems to be predilection for immunocompromised patients, intracranial leiomyomas affect both sexes equally, most commonly in the second and third decades of life [1]. The majority of patients do not present with symptoms, however, and the lesions are often found incidentally [1]. Imaging can aid in suggesting the diagnosis of an intracranial leiomyoma due to its characteristic features. On MRI, leiomyomas will appear as a homogenous iso- or hypointense lesion on T1-weighted imaging and as a heterogeneous hyper- or hypointense lesion on T2-weighted imaging; hypointensity is reported most commonly $[1,5-8,16,19]$. They enhance with contrast administration and their appearance is most similar to meningioma. Though the imaging can aid in narrowing the differential diagnosis, immunohistochemistry must be done in order to confirm the diagnosis. Upon staining, a leiomyoma will be positive for alpha-actin, desmin, myosin, and vimentin, and negative for S100 [1,20,21]. Histology reveals spindle shaped cells with blunt ends and few mitotic figures, which help in distinguishing it from the highly malignant leiomyosarcoma with a high number of mitotic figures and strong expression of MIB-1 [1,22].

The best treatment option to date for primary intracranial leiomyomas remains surgical gross total resection without adjuvant radiation therapy [1]. There is one case report in the literature that postulates an intracranial leiomyoma transitioning to leiomyosarcoma post radiation therapy therefore suggesting that if a resection is subtotal, observation may be warranted [23]. No general recommendations for long-term follow-up have been made secondary to the paucity of data, rarity of the disease, and the trend that the majority of the patients 
Citation: Fornoff LE, Nelson KS, McComb RD, Hellbusch LC, Aizenberg MR (2013) Primary Intracranial Leiomyoma in Immunocompetent Patients:

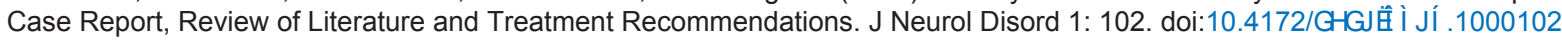

with primary intracranial leiomyomas are immunosuppressed and have therefore died from other co-morbidities [3,5-7, 9,11,17]. Our patient had a small recurrence found 108 months after his primary resection. Table 1 identifies similar intracranial cases with the longest follow-up of 84 months [17]. These cases illustrate the need for longterm follow-up in patients with this rare disease given both its slowgrowing nature and prolonged recurrence time frame. In addition, it is suggested that resection be followed by observation only considering the protracted course of these tumors in both the immunocompetent and immunocompromised patient.

\section{References}

1. Hua W, Xu F, Mao Y, Zhang J, Wang Y, et al. (2009) Primary intracranial leiomyomas: Report of two cases and review of the literature. Clin Neurol Neurosurg 111: 907-912.

2. Alessi G, Lemmerling M, Vereecken L, De Waele L (2003) Benign metastasizing leiomyoma to skull base and spine: a report of two cases. Clin Neurol Neurosurg 105: 170-174.

3. Joseph V, Chacko G, Raghuram L, Rajshekhar V (2003) Benign metastasizing leiomyoma causing spinal cord compression. Surg Neurol 60: 575-577.

4. Lee HJ, Choi J, Kim KR (2008) Pulmonary benign metastasizing leiomyoma associated with intravenous leiomyomatosis of the uterus: clinical behavior and genomic changes supporting a transportation theory. Int J Gynecol Pathol 27: 340-345.

5. Ali AE, Fazl M, Bilbao JM (2006) Primary intracranial leiomyoma: a case report and literature review. Virchows Arch 449: 382-384.

6. Bargiela A, Rey JL, Diaz JL, Martinez A (1999) Meningeal leiomyoma in an adult with AIDS: CT and MRI with pathological correlation. Neuroradiology 41: 696-698.

7. Citow JS, Kranzler L (2000) Multicentric intracranial smooth-muscle tumor in a woman with human immunodeficiency virus. Case report. J Neurosurg 93: 701-703.

8. Dorwal P, Kaul S, Arora D, Prasad R (2010) Intracranial leiomyoma in a male patient. Indian J Pathol Microbiol 53: 837-839.

9. Karpinski NC, Yaghmai R, Barba D, Hansen LA (1999) Case of the month: March 1999--A 26 year old HIV positive male with dura based masses. Brain Pathol 9: 609-610.
10. Kim SH, Youm JY, Song SH, Kim Y, Song KS (1999) Primary intracranial leiomyoma. Case illustration. J Neurosurg 90: 171.

11. Kleinschmidt-DeMasters BK, Mierau GW, Sze CI, Breeze RE, Greffe B, et al (1998) Unusual dural and skull-based mesenchymal neoplasms: a report of four cases. Hum Pathol 29: 240-245.

12. Kroe DJ, Hudgins WR, Simmons JC, Blackwell CF (1968) Primary intrasellar leiomyoma. Case report. J Neurosurg 29: 189-191.

13. Kumar S, Santi M, Vezina G, Rosser T, Chandra RS, et al. (2004) EpsteinBarr virus-associated smooth muscle tumor of the basal ganglia in an HIV+ child: case report and review of the literature. Pediatr Dev Pathol 7: 198-203.

14. Lin SL, Wang JS, Huang CS, Tseng HH (1996) Primary intracerebra leiomyoma: a case with eosinophilic inclusions of actin filaments Histopathology 28: 365-369.

15. Thierauf $P$, Weiland $H$ (1978) Intracranial leiomyoma. Med Welt 29: 1280 1312.

16. Wang KC, Kim CJ, Cho BK, Kim IO, Lee HJ, et al. (1997) Cerebral leiomyoma in a child. J Korean Med Sci 12: 378-382.

17. Zevgaridis D, Tsonidis C, Kapranos N, Venizelos I, Tsitsopoulos P (2009) Epstein-Barr virus associated primary intracranial leiomyoma in organ transplant recipient: case report and review of the literature. Acta Neurochir (Wien) 151: 1705-1709.

18. Kazumoto K KS, Matsumoto M (1992) Primary intracranial leiomyoma: report of a case. Brain Tumor Pathology 9: 87-89.

19. Lai PH, Yang CF, Huang CH, Yeh LR, Lin SL, et al. (1998) Primary intracrania leiomyoma: case report. Neuroradiology 40: 238-241.

20. Lach B, Duncan E, Rippstein P, Benoit BG (1994) Primary intracranial pleomorphic angioleiomyoma new morphologic variant. An immunohistochemical and electron microscopic study. Cancer 74: 1915-1920.

21. Hashimoto H QB (2002) Leiomyoma of deep tissue. (4thedn): IARC Press.

22. Hussain S, Nanda A, Fowler M, Ampil FL, Burton GV (2006) Primary intracranial leiomyosarcoma: report of a case and review of the literature. Sarcoma 2006: 52140 .

23. Jakobiec FA, Howard GM, Rosen M, Wolff M (1975) Leiomyoma and leiomyosarcoma of the orbit. Am J Ophthalmol 80: 1028-1042. 